\title{
The Ninety-Nine Percent and the One Percent
}

\author{
Salman Sakir, ${ }^{1 *}$ \\ ${ }^{1}$ Independent Researcher, P.O. Box 20581, 390 Rideau Street East, Ottawa, ON K1N 5W0, \\ Canada \\ *Correspondence: Tel: 1-613-400-3280. E-mail: salmansakir@yahoo.com
}

Received: July 19, 2014 Accepted: August 14, 2014 Published: September 24, 2014

doi:10.5296/rae.v6i3.5996 URL: http://dx.doi.org/10.5296/rae.v6i3.5996

\begin{abstract}
This paper explores income inequality from different angles. It tries to understand the possible reasons for income inequality that exist in the modern world. It supports the notion that exceptionally talented individuals using technology has been a reason behind rising income inequality. The paper explores whether this has been the only reason for rising global income inequality. It suggests that there may be other possible reasons, one of which is globalization
\end{abstract}

Again, the paper explores the arguments for and against the ninety-nine percent and the one percent. It analyzes whether the income of the middle-class has really remained the same and argues that their income may not have necessarily stayed the same. It explores the case for higher taxation on the rich.

It analyzes the consequences of income inequality on human development for countries at different stages of human development. The paper finds that the relationship between the Gini coefficient and human development is different for countries at various stages of human development. However, it finds that income inequality reduces human development for all countries irrespective of the stage of human development.

Finally, the paper explores the relationship between income inequality and poverty level for the United States. It finds that poverty level in the US did not increase even though income inequality has increased.

Keywords: Income inequality, 99 percent, 1 percent, Income inequality in the US 


\section{Introduction}

Income inequality is an issue that has gained substantial attention. It has increased significantly in the last few decades all over the world in both developing and developed countries, including the United States. Some people argue that these inequalities are a result of some people's unique talents combined with technology to earn extraordinary levels of income. Others like Joseph Stiglitz argue that the main reason for income inequality in the United States is rent seeking. As there are diverse explanations, it is important to explore the possible reasons of income inequality. It is also important to explore the possible consequences of an unequal world.

\section{Is perfect equality efficient?}

An utopian society which has perfect equality may seem ideal and just. However, most economists would agree that perfect equality is not efficient. In reality, people are endowed with different levels of skills and talents; also, they are willing to put in various levels of effort. It is important to reward individuals based on their performance for a society to progress. As people are paid based on their marginal productivity in a market economy, perfect equality is not efficient for the dynamic functioning of an economy.

\section{Is inequality efficient?}

Perfect inequality, a situation where one person or a group of people have all the wealth in a country, would be considered inefficient and morally wrong by most people. However, most people would agree that some degree of inequality is needed for a society to progress.

Claudia Goldin and Lawrence Katz (2008) make a convincing argument in their book The Race between Education and Technology regarding the United States. According to their argument, the increase of educated workers was higher than the demand for them before 1980 . This resulted in higher income for most people and lower inequality. However, from about 1980, there has been an educational slow-down in the United States that has led to rising income inequality.

I am convinced by Mankiw (2013) when he writes, "Rather, it seems that changes in technology have allowed a small number of highly educated and exceptionally talented individuals to command superstar incomes in ways that were not possible a generation ago." Many of the technology entrepreneurs have made important inventions that have made them very wealthy. Similarly, Kaplan and Rauh (2013) make a convincing argument when they state that scale and skill-based technological change have attributed to the superstar incomes of the top 1 percent in the US.

All the papers mentioned above study the income inequality in the US. When thinking globally, I am not convinced that a combination of talented individuals leveraging technology is the sole reason for the global income inequality. I would argue that there are other possible 
reasons for the growing global income inequality. Rent-seeking, crony capitalism, exploitation of cheap labor, globalization, lower income tax rates, transfer pricing and tax havens are some of the factors that may have played roles in contributing to global income inequality. The contribution of crony capitalism to income inequality may especially be true in developing countries where laws are weak and easier to circumvent. Bivens and Mishel (2013) make a case for the US that the incomes and wages of the top 1 percent have increased over the last three decades due to creation and redistribution of economic rents. It is possible that rent seeking has been one of the reasons for driving global income inequality. Again, transfer pricing may also have perpetuated income inequality. Prem and Willmott (2010) mention that companies take advantage of transfer pricing to reduce their taxes in both developed and developing countries. This increases the after tax income of these companies. The shareholders of these companies benefit in terms of higher incomes. Therefore, exploitation of transfer pricing opportunities by companies may lead to rising income inequality. Finally, tax havens may also play a role in rising income inequality. When a company is registered in a tax haven, it is not paying any tax that allows it to retain most of its profits. As the owners and shareholders of the company repatriate the profits back to their respective countries, they have a higher after-tax income. The use of tax havens may also have contributed to the growing global income inequality.

\section{Are there differences in opportunity?}

Mankiw (2013) argues that the educational and career opportunities available to children of the top 1 percent are not very different from those available to the middle class. His argument is based on analysis of the US society. I would argue that globally this is not the case. First of all, there is a significant difference in availability of opportunity between children living in developed countries and children living in developing countries. More importantly, I would argue that in developing countries, there is significant difference in the opportunities available to the children of the top 1 percent and that of the middle class.

Corak (2013), while analyzing US data, mentions that inequality lowers mobility as it shapes opportunity. She writes, "It heightens the income consequences of innate differences between individuals; it also changes opportunities, incentives, and institutions that form, develop, and transmit characteristics and skills valued in the labor market; and it shifts the balance of power so that some groups are in a position to structure policies or otherwise support their children's achievement independent of talent. Thus, those who are concerned about equality of opportunity should also care about inequality of outcomes, but only to the extent that these differences in outcomes are due." Therefore, even in the US, there may be substantial differences in opportunity for the children due to differences in income levels of the parents. The differences in opportunity lead to differences in income of the children. This may not be desirable for a society, as a system based on meritocracy is far more dynamic and sustainable in the long run.

It is possible that there may be a correlation between family income and external environment, especially the school system. A low-income family may not be able to afford to send their 
children to a school that provides quality education. This may influence the children's potential income as suggested by Chetty and Friedman (2011). They write, "If richer families sort into school districts that spend more to produce higher quality education, and quality of education has a causal impact on children's incomes, then local financing of public schools may propagate income inequality." This indicates how the income of the parents may influence the income of the children. In general, low-income families will locate in areas which have lower property taxes while high-income families will move to rich neighborhoods where property taxes are higher. When property taxes constitute a substantial portion of funding for public schools, the schools that high-income families' children attend can spend more to provide quality education than the schools that low-income families' children attend. The quality of education influences children"s income and has an impact on income inequality.

Chetty, Friedman and Rockoff (2011) state that students who are assigned high value added (HVA) teachers are more likely to earn higher salaries. They add that these students are more likely to attend college, attend higher-ranked colleges, live in higher socioeconomic status neighborhoods, save more for retirement and are less likely to have children as teenagers. A good teacher (high value-added teacher) would want to teach in a school which pays well and can provide resources that allow him to teach well. In that case, the teacher is more likely to teach in an urban area where schools pay higher salaries and have more resources. Schools that pay well and have access to more resources are usually located in rich neighborhoods where high-income families reside. Therefore, children coming from high-income families will have access to good teachers that will give them a better education and, ultimately, an advantage in terms of higher potential income relative to children coming from low-income families.

A low-income family may afford to live in a neighborhood where there are not enough playgrounds and crime rates are high. Also, there may be inadequate social services in those areas compared to an affluent neighborhood. On the other hand, a high-income family can afford to live in a rich neighborhood which has adequate playgrounds and open spaces. They may live in a gated community where crime rates are low. This may allow the child to live a healthy life and, possibly, be less prone to drug abuse. A healthy and safe childhood may make a healthy adult who earns high salaries. The neighborhood may have an influence on a child's potential income and the choice of the neighborhood is in turn determined by the family's income.

\section{Have wages really remained the same?}

One popular argument of those that criticize income inequality is that the income of the middle class in the United States has remained the same over the last two decades. However, during this period, the whole world, including the United States, experienced significant globalization and international trade. There are imports of goods from China and other low labor cost countries.

Now, if the imported goods are cheaper than the domestically produced goods (which is 
obviously the case), the consumers are buying the same products at lower prices. Given a constant nominal income, a decrease in prices would mean that the purchasing power of the consumers has increased. So, it is possible that the income of the middle class may not have remained the same in the last two decades. More research needs to be done before one can conclude about the trend in income of the middle class in the US in the last two decades.

\section{Should the rich pay more?}

There is a lot of contention and debate between the left and the right about the rich paying higher taxes. Mankiw (2013) states that in the US, the average person in the top 1 percent pays about one-third of income in taxes. He adds, 'Why isn't that enough to compensate for the value of government infrastructure?' It is normative to ask what should be the ideal contribution of the rich. According to the benefits principle, the rich use more of the infrastructure than the poor or the middle class. A middle-class person who takes the bus to work and an affluent person who is chauffeur-driven in a Rolls Royce to work do not use the roads the same way. While the bus can accommodate many people, the rich individual usually has the car all to himself. So, the infrastructure use per capita of the middle-class who take the bus is less than the infrastructure use per capita of the rich. If pricing is adjusted to usage, it means that the rich should pay more for his use of roads and highways.
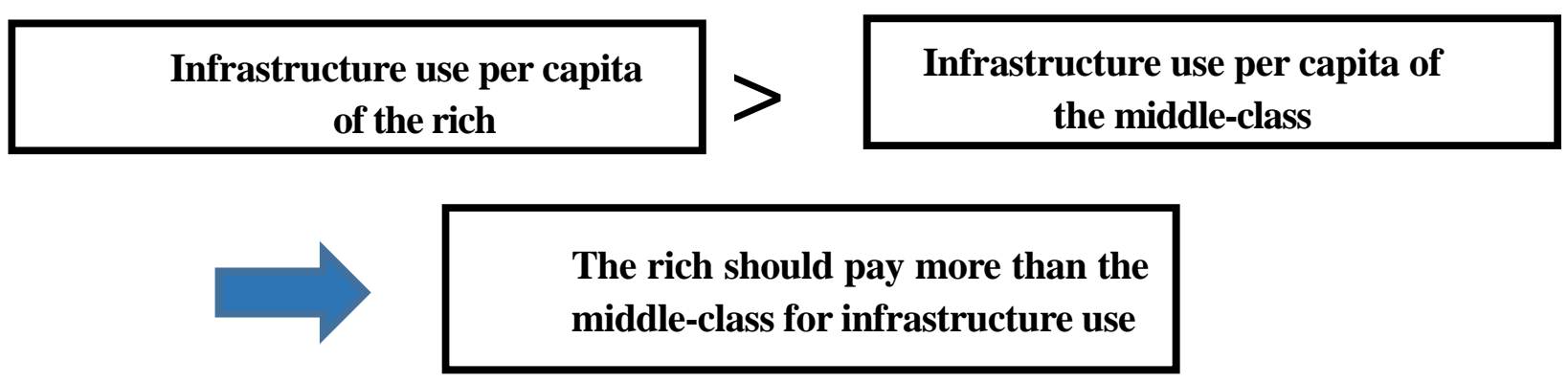

Now, how much more the rich should pay is a normative question. However, it needs to be asserted that the 'just' contribution of the rich is dynamic in nature. It would vary between countries and over time. In a developed country, where infrastructure is widely used by everybody, the rate will be different from a developing country where the rich are mostly using the infrastructure and are the main beneficiaries of infrastructure use.

Mankiw (2013) builds logic between kidney donation and people enjoying their income. He writes, "If imagining a hypothetical social insurance contract signed in an original position does not supersede the right of a person to his own organs, why should it supersede the right of a person to the fruits of his own labor?" I do not find this comparison very convincing. It is true that most people would not agree to a policy of government-mandated kidney donation. However, most people, including the rich, would want to be taxed which would bring them benefits, both monetary and non-monetary. Non-monetary benefits may include safety and security. So, safer streets and lower crimes may justify in the rich contributing more to tax revenues. Safer streets and lower crimes may also incentivize the rich to contribute more. A 
potential criminal would target a millionaire more than a homeless person for the simple reason that the millionaire has more assets that can be 'taken' from him. As the millionaire may lose more than the homeless person when law and order breaks down, he has a greater incentive to pay more taxes that will finance programs to keep the streets safe and secure his wealth.

One may wonder why most of the affluent people are from developed countries. It is true that the affluent people have used creativity and hard work to become rich. However, is it also possible that just by living in rich countries, people benefit far more than just enjoying the infrastructure, healthcare and education? Could Bill Gates become one of the richest people on the planet if he lived in a least developed country? In all probability, the answer is no. If that is the case, I would argue that the affluent should pay for the privilege of living in a rich country which gives them enormous opportunities and allows them to reach their potential. A counterargument can be that everybody living in a rich country enjoy the benefits; so, why should the affluent contribute more for living in a rich country. However, the affluent, inspite of their talent and hard work, would have far less chance of succeeding if they lived in a developing country. So, the affluent should pay a 'premium' for living in a rich country.

Mankiw (2013) writes, "Many economists do support increased foreign aid, but as far as I know, no one has proposed marginal tax rates on rich nations as high as the marginal tax rates imposed on rich individuals. Our reluctance to apply utilitarianism at the global level should give us pause when applying it at the national level". I don't think the same rule applies when imposing marginal tax rates on rich individuals as compared to rich nations. Even after considering international trade, a nation becomes rich mostly because of its own resources and other intrinsic factors. I don't think one country becomes rich because of the efforts and attributes of another country. As a rich country is not 'indebted' to another country for becoming rich, it should not have any compulsion to pay a high marginal tax. But, as the previous paragraph argues, the rich individual's success is tied to the rich country. Therefore, the rich individual should contribute more to the society that allows him to be affluent.

\section{Technological innovation and cheap labor}

The world has experienced significant technological innovation. There have been enormous contributions by innovators and entrepreneurs. Mankiw (2013) mentions the development of the iPod by Steve Jobs. Innovators and entrepreneurs like Steve Jobs have made substantial technological and economic contributions to the society while becoming wealthy themselves. It is very important for a society's progress to reward innovation and entrepreneurship. Having said that, one of the manufacturers of iPhones, iPods and iPads is Foxconn, the largest electronic contract manufacturer in the world, has been plagued by allegations of poor working conditions and cases of suicide among its employees in China. The allegations have ranged from long working hours, poor working conditions and insufficient overtime pay. Also, the incidences of suicide among Foxconn employees have been linked to low pay. At one point, Foxconn installed suicide-preventing nets at some factories and promised to increase wages in some factories. Foxconn is a very successful company and its owner, Terry 
Gou, is a billionaire; however, its employees were subjected to harsh working conditions and poor wages. A relevant question to ask is how much of Apple's profit can be attributed to innovation and how much can be attributed to the exploitation of cheap labor in the manufacturing process. It is true that manufacturing of iPods and iPads has created employment in China and other countries; it may even be true that the workers have more income than before but, that does not mean that the workers have to be exposed to harsh working conditions and low wages. More research and analysis need to be done to understand the share of innovation and the share of exploitation of cheap labor in a company's profit.

\section{Globalization and Income Inequality}

The ranks of the super wealthy have swelled in the last few decades, from the time globalization really took off. Globalization has allowed entrepreneurs to reach consumers in all parts of the world; it has increased the consumer base for multinational companies. However, it has also allowed companies to produce in a low-wage country (that usually has less stringent labor laws and environmental laws) and sell in a high-income country. This case falls under the category of comparative advantage to participate in international trade; globalization has allowed companies, and their respective owners and shareholders to maximize their wealth. Increased trade and globalization has been beneficial for both developed countries and developing countries. However, I would argue that it has opened up increased opportunities to exploit labor in low- income countries.

An appropriate example of this is found with the clothing chain, Inditex. The company operates thousands of clothing stores worldwide while it manufactures clothing in low-wage countries like Bangladesh. The founder of Inditex, Amancio Ortega Gaona, is worth US \$57 billion while a worker in Bangladesh producing clothing for Inditex may earn as low as US $\$ 38$ per month. The opportunity to manufacture clothing in low-wage countries where workers are paid a fraction of the price that the company charges customers in high-income countries has made Inditex and its founder very wealthy. Similar situations can be seen for other global companies. Stiglitz (2012) writes that the wealth of the six Walmart heirs equals that of the entire bottom 30 percent of the US population. A closer observation will reveal that Walmart procures its products from low-cost countries like China and Bangladesh and sells them in high-income countries. It is possible that globalization has allowed entrepreneurs and global companies to take advantage of discrepancies in the global marketplace and exploit them for their own benefits. Further research can be done to explore globalization's impact on inter and intra- country income inequality.

\section{Is income inequality that bad?}

There are some arguments against income inequality. Stiglitz (2012) states that income inequality undermines productivity and retards economic growth. He adds that a more egalitarian society would result in a more stable economy. 
A high level of inequality and opportunity may create a situation when an individual feels that he cannot move up the economic ladder inspite of the level of effort and talent. This may dissuade the person from working hard and try to move up the ladder. As a result, labor productivity in the society may decrease that may reduce economic growth. Again, a high level of income inequality in a country may decrease the social cohesion in the society. The rich may feel superior and different from the masses while the average person may view the rich with contempt and resentment. This may lead to less social cohesion that is not helpful for the society and may lead to lower economic development in the country. However, initiatives like The Giving Pledge started by Bill Gates and Warren Buffett may reverse the decrease of social cohesion in the society. I would argue that when the average person perceives that the rich have made their fortunes by engaging in illegal practices like rent-seeking, corruption and crony capitalism, there may be less social cohesion in the society which is detrimental to the country's development.

There is a debate between two renowned economists, Jagdish Bhagwati and Amartya Sen, on the best way to achieve inclusive growth in India. The former said that poverty decreases due to economic growth and achieving high growth rates is the way to reduce poverty. On the other hand, Amartya Sen has suggested that poverty has decreased due to redistribution of wealth. It has been observed for sometime in emerging economies that high economic growth has been accompanied by rise in income inequality. China grew at high growth rates which were sometimes over 10 percent to become the second-largest economy in the world. It has been able to pull out 680 million people out of poverty while income inequality increased in that country. The same phenomenon of rising inequality coupled with poverty reduction has been observed in many emerging economies. It seems that income inequality is not that bad when poverty is decreasing and the country experiences high rates of economic growth. However, this phenomenon is observed in the case of developing countries. Countries like the US or the UK which have mature economies have experienced an increase in per capita income while income inequality also increased, thus defying the Kuznets curve. Further research need to be conducted to see the relationship between growing income inequality, economic growth and poverty reduction for both developed and developing countries.

An interesting observation is the impact of income inequality on human development. Figure 1 shows the relationship between Human Development Index (HDI) and Gini coefficient of very high human development countries. It shows that as income inequality increases, HDI decreases. In very high human development countries (which are usually the rich countries), an increase in income inequality may mean that some people cannot allocate sufficient resources to health and education because of lower income. This would decrease the overall HDI of very high HDI countries. Again, Figure 3 shows the same relationship between HDI and Gini coefficient for high HDI countries. This graph also shows a negative relationship between HDI and Gini coefficient. However, the line is less steep, so that an increase in Gini coefficient does not decrease HDI as much as for very high HDI countries. Figure 5 shows almost a horizontal line for HDI and Gini coefficient of medium HDI countries so that an increase in income inequality does not seem to have an impact on the HDI of the country. Finally, Figure 7 shows the positive relationship between HDI and Gini coefficient for low 


\section{Macrothink Institute ${ }^{\mathrm{TM}}$}

HDI countries. Most of these countries are least developed countries and people can spend very little on education and health. With economic growth, some people are gaining more income that allows them to spend more on education and health. This increases income inequality but, at the same time, increases the HDI of the country.

These four graphs raise an important question regarding wealth. For very high and high HDI countries, there is a negative relationship between HDI and Gini coefficient which raises the possibility of wealth transfer from the poor and middle class to the rich in high or very high HDI countries. It also raises the issue of reducing income inequality to improve human development. As Figures 2, 4, 6 and 8 show, there is a difference in inequality-adjusted HDI (IHDI) and HDI for all four types of countries. The graphs indicate that a reduction in income inequality in any type of country would improve human development. This suggests that any society, irrespective of its human development, would benefit from a reduction in income inequality. The data used to construct Figure 1 to Figure 8 are shown in Tables 1 to 4 .

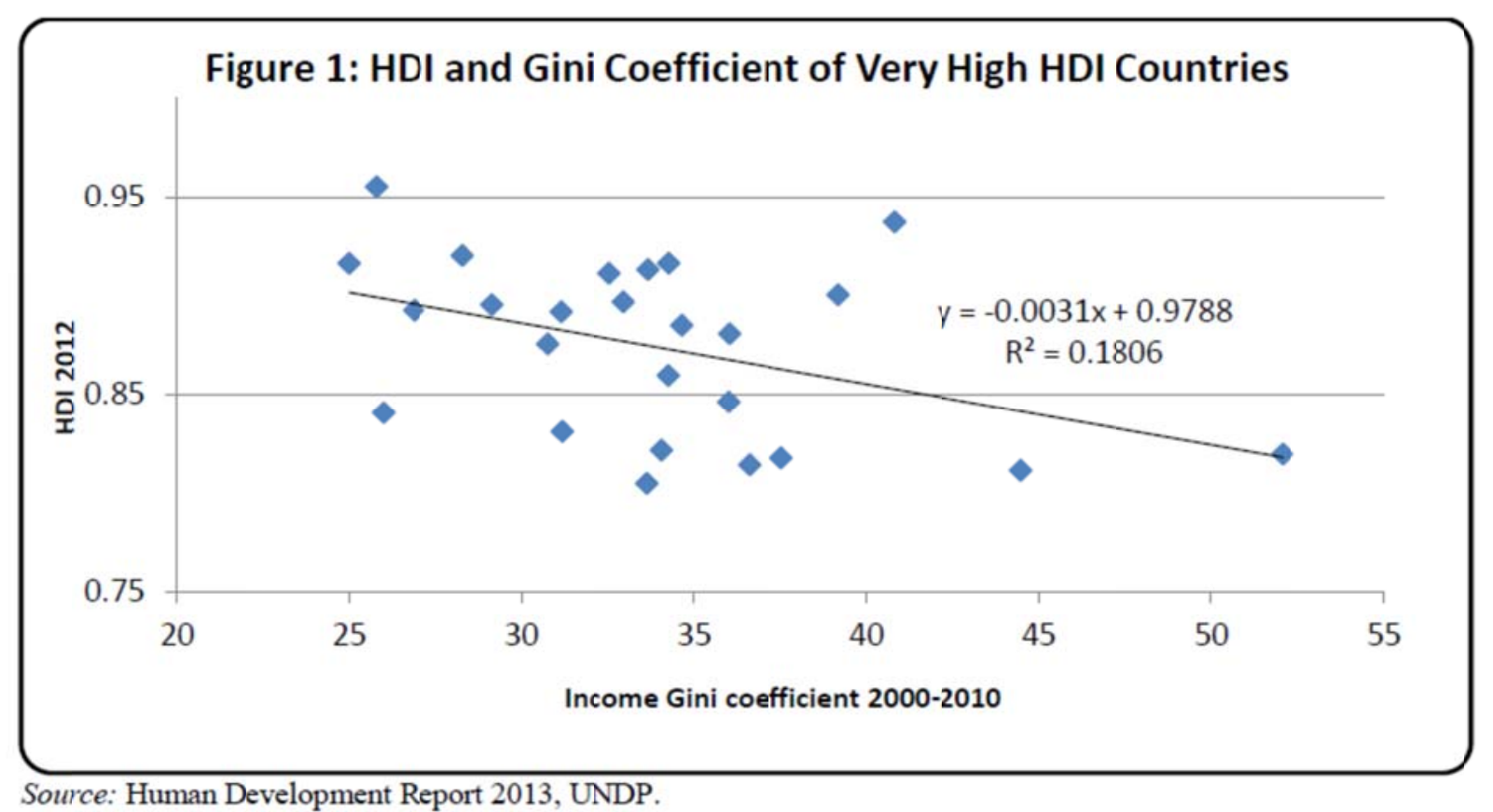

Source: Human Development Report 2013, UNDP.

Figure 1. HDI and Gini Coefficient of Very High HDI Countries 


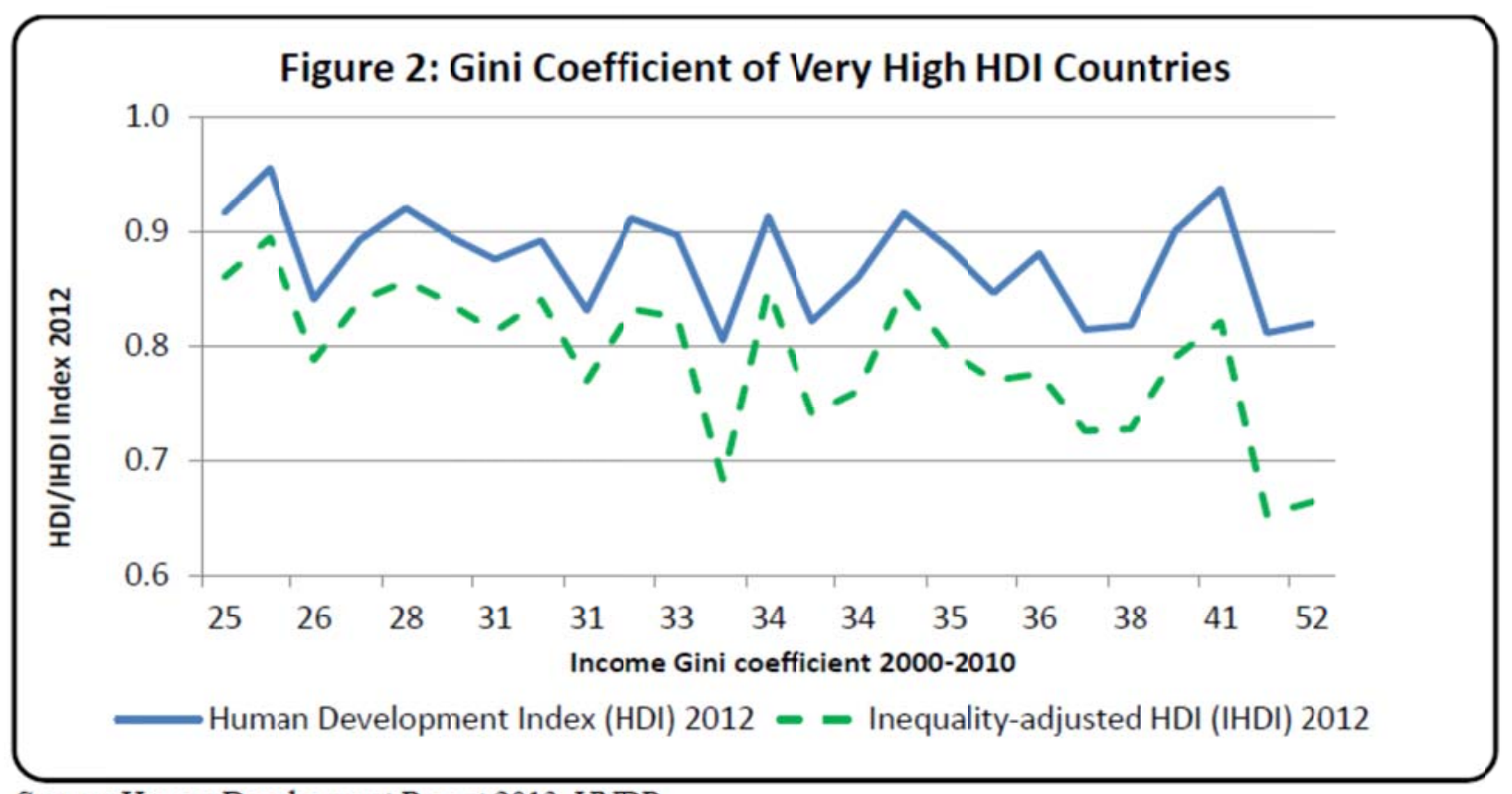

Source: Human Development Report 2013, UNDP.

Figure 2. Gini Coefficient of Very High HDI Countries

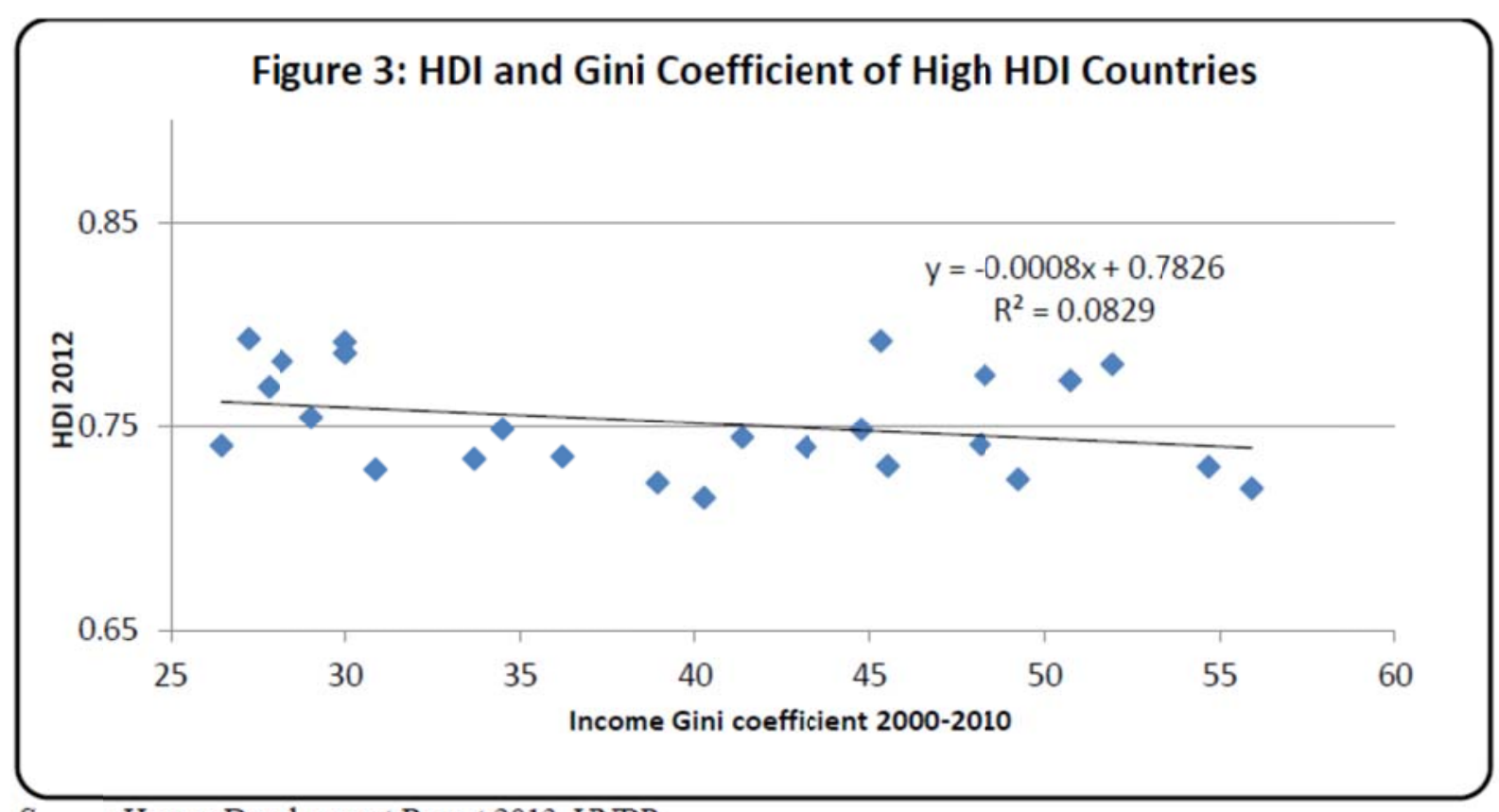

Source: Human Development Report 2013, UNDP.

Figure 3. HDI and Gini Coefficient of High HDI Countries 


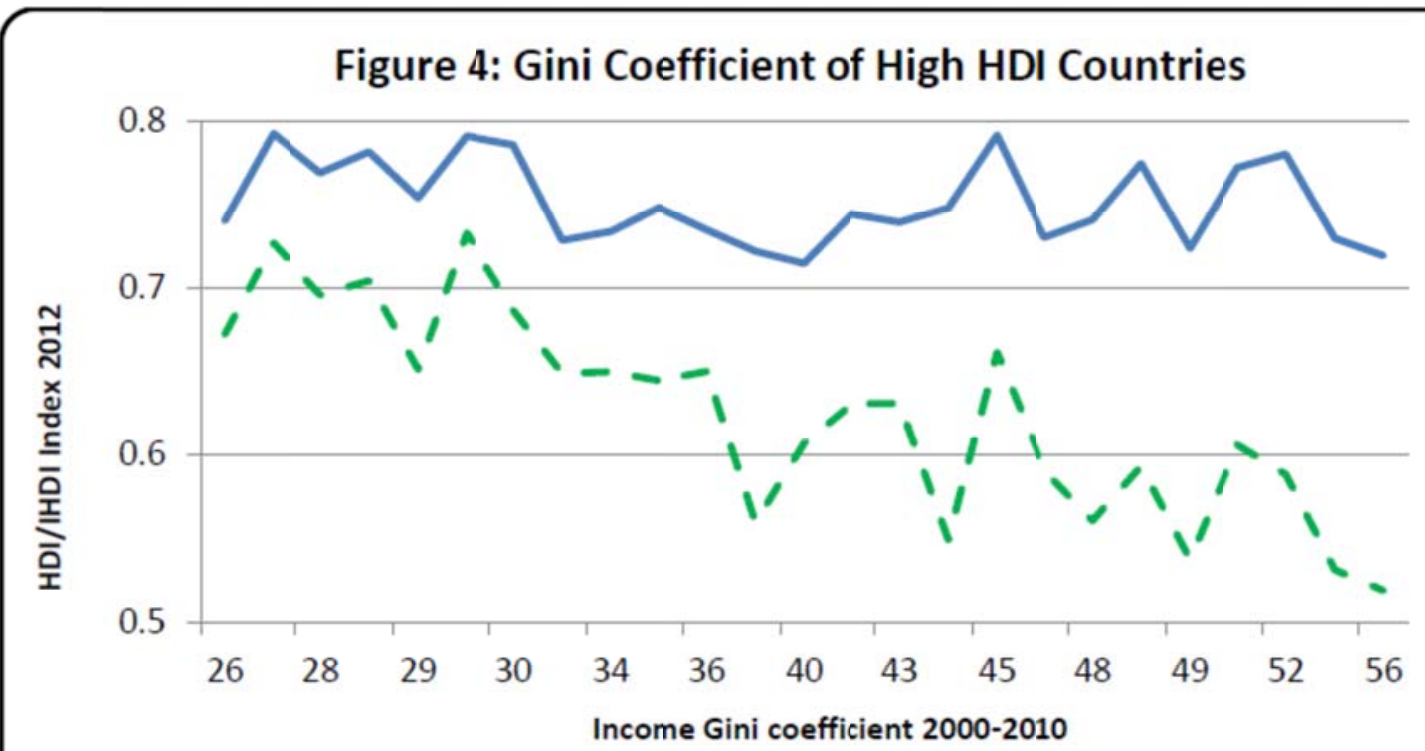

-Human Development Index (HDI) 2012 - - Inequality-adjusted HDI (IHDI) 2012

Source: Human Development Report 2013, UNDP.

Figure 4. Gini Coefficient of High HDI Countries

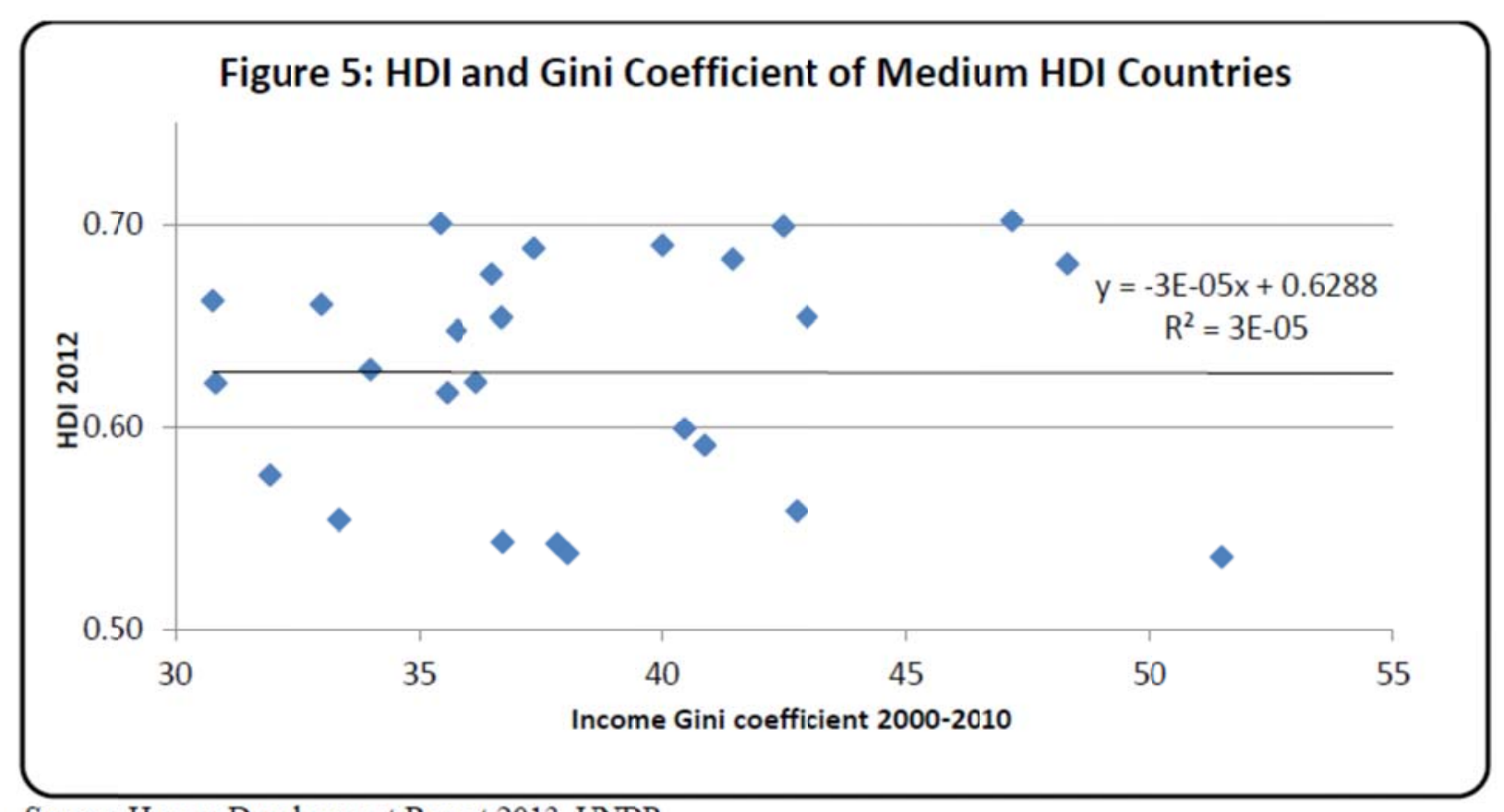

Source: Human Development Report 2013, UNDP.

Figure 5. HDI and Gini Coefficient of Medium HDI Countries 


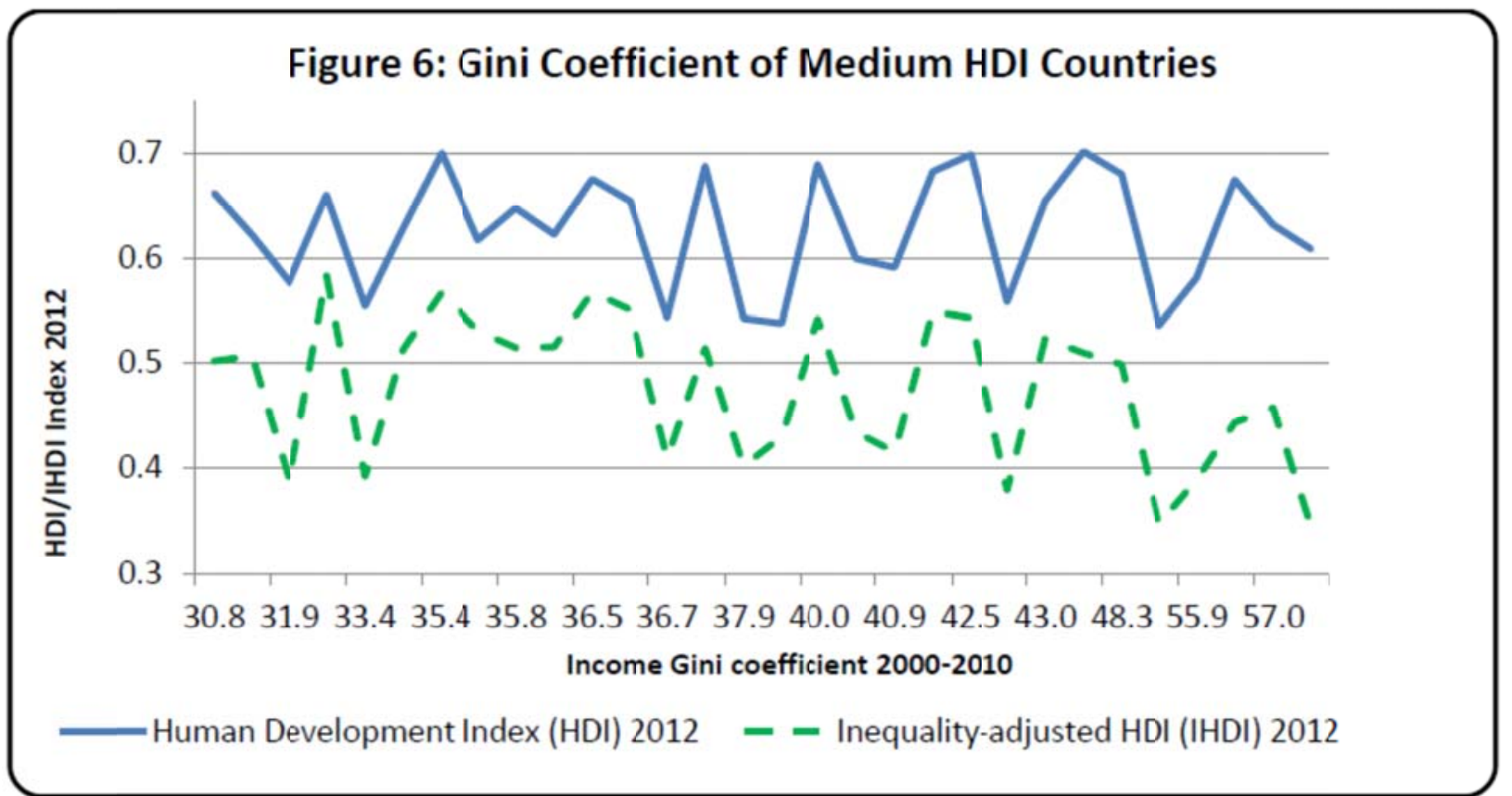

Source: Human Development Report 2013, UNDP.

Figure 6. Gini Coefficient of Medium HDI Countries

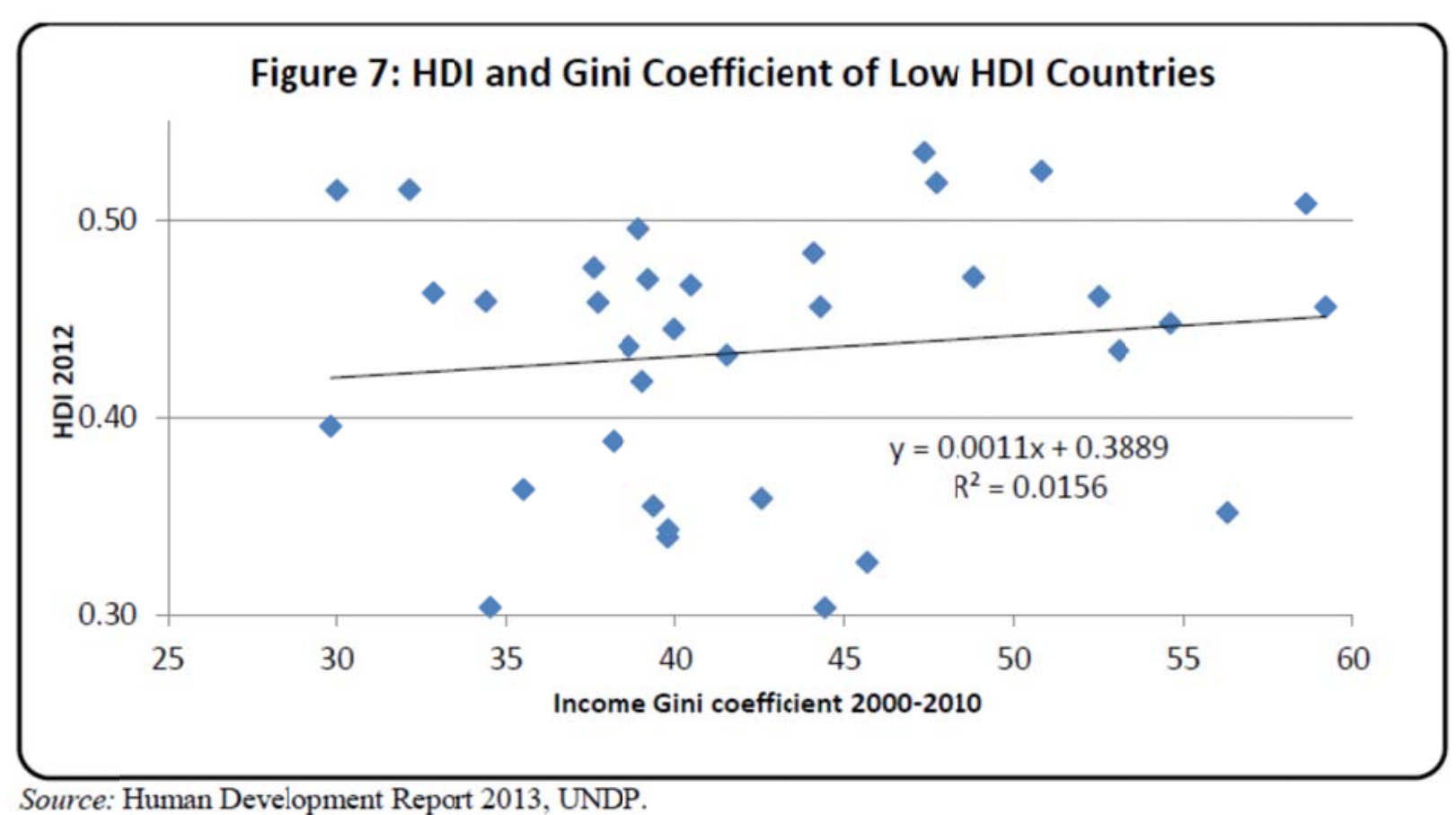

Figure 7. HDI and Gini Coefficient of Low HDI Countries 


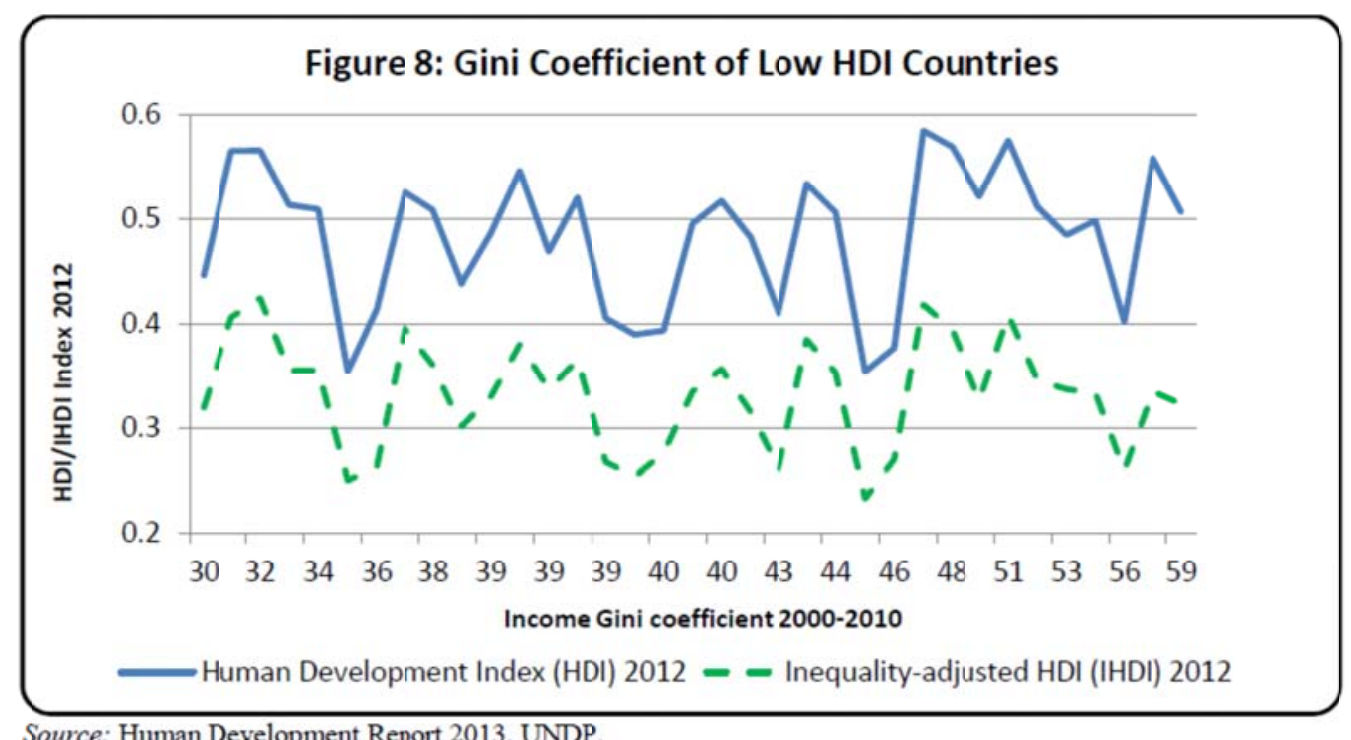

Source: Human Development Report 2013, UNDP.

Figure 8. Gini Coefficient of Low HDI Countries

Table 1. HDI and Gini Coefficient of Very High HDI Countries

\begin{tabular}{lccc}
\hline \multicolumn{1}{c}{ Country } & $\begin{array}{c}\text { Human Development } \\
\text { Index (HDI) 2012 }\end{array}$ & $\begin{array}{c}\text { Inequality-adjusted } \\
\text { HDI (IHDI) 2012 }\end{array}$ & $\begin{array}{c}\text { Income Gini coefficient } \\
\mathbf{2 0 0 0 - 2 0 1 0}\end{array}$ \\
\hline Sweden & 0.916 & 0.859 & 25.0 \\
Norway & 0.955 & 0.894 & 25.8 \\
Slovakia & 0.840 & 0.788 & 26.0 \\
Finland & 0.892 & 0.839 & 26.9 \\
Germany & 0.920 & 0.856 & 28.3 \\
Austria & 0.895 & 0.837 & 29.2 \\
Luxembourg & 0.875 & 0.813 & 30.8 \\
Slovenia & 0.892 & 0.840 & 31.2 \\
Hungary & 0.831 & 0.769 & 31.2 \\
Canada & 0.911 & 0.832 & 32.6 \\
Belgium & 0.897 & 0.825 & 33.0 \\
Croatia & 0.805 & 0.683 & 33.7 \\
Switzerland & 0.913 & 0.849 & 33.7 \\
Poland & 0.821 & 0.740 & 34.1 \\
Greece & 0.860 & 0.760 & 34.3 \\
Ireland & 0.916 & 0.850 & 34.3 \\
Spain & 0.885 & 0.796 & 34.7 \\
Estonia & 0.846 & 0.770 & 36.0 \\
Italy & 0.881 & 0.776 & 36.0 \\
Latvia & 0.814 & 0.726 & 36.6 \\
Lithuania & 0.818 & 0.727 & 37.6 \\
Israel & 0.900 & 0.790 & 39.2 \\
United States & 0.937 & 0.821 & 40.8 \\
Argentina & 0.811 & 0.653 & 44.5 \\
Chile & 0.819 & 0.664 & 52.1 \\
\hline Source: & & &
\end{tabular}

Source: Human Development Report 2013, UNDP. 
Table 2. HDI and Gini Coefficient of High HDI Countries

\begin{tabular}{lccc}
\hline Country & $\begin{array}{c}\text { Human } \\
\text { Development Index } \\
\text { (HDI) 2012 }\end{array}$ & $\begin{array}{c}\text { Inequality-adjusted } \\
\text { HDI (IHDI) 2012 }\end{array}$ & $\begin{array}{c}\text { Income Gini } \\
\text { coefficient } \\
\text { 2000-2010 }\end{array}$ \\
\hline Ukraine & 0.740 & 0.672 & 26.4 \\
Belarus & 0.793 & 0.727 & 27.2 \\
Serbia & 0.769 & 0.696 & 27.8 \\
Bulgaria & 0.782 & 0.704 & 28.2 \\
Kazakhstan & 0.754 & 0.652 & 29.0 \\
Montenegro & 0.791 & 0.733 & 30.0 \\
Romania & 0.786 & 0.687 & 30.0 \\
Armenia & 0.729 & 0.649 & 30.9 \\
Azerbaijan & 0.734 & 0.650 & 33.7 \\
Albania & 0.749 & 0.645 & 34.5 \\
Bosnia and Herzegovina & 0.735 & 0.650 & 36.2 \\
Turkey & 0.722 & 0.560 & 39.0 \\
Sri Lanka & 0.715 & 0.607 & 40.3 \\
Georgia & 0.745 & 0.631 & 41.3 \\
The former Yugoslav Republic of & 0.740 & 0.631 & 43.2 \\
Macedonia & & & \\
Venezuela (BolivarianRepublic of) & 0.748 & 0.549 & 44.8 \\
Uruguay & 0.792 & 0.662 & 45.3 \\
Jamaica & 0.730 & 0.591 & 45.5 \\
Peru & 0.741 & 0.561 & 48.1 \\
Mexico & 0.775 & 0.593 & 48.3 \\
Ecuador & 0.724 & 0.537 & 59.3 \\
Costa Rica & 0.773 & 0.606 & 54.7 \\
Panama & 0.780 & 0.588 & 55.9 \\
Brazil & 0.730 & 0.531 & \\
Colombia & 0.719 & 0.519 & \\
\hline Source & & & \\
\hline
\end{tabular}

Source: Human Development Report 2013, UNDP. 


\section{Al Macrothink}

Research in Applied Economics

ISSN 1948-5433

2014, Vol. 6, No. 3

Table 3. HDI and Gini Coefficient of Medium HDI Countries

\begin{tabular}{|c|c|c|c|}
\hline Country & $\begin{array}{c}\text { Human } \\
\text { Development Index } \\
\text { (HDI) } 2012\end{array}$ & $\begin{array}{c}\text { Inequality-adjusted } \\
\text { HDI (IHDI) } 2012\end{array}$ & $\begin{array}{c}\text { Income Gini } \\
\text { coefficient } \\
2000-2010\end{array}$ \\
\hline Egypt & 0.662 & 0.503 & 30.8 \\
\hline Tajikistan & 0.622 & 0.507 & 30.8 \\
\hline Timor-Leste & 0.576 & 0.386 & 31.9 \\
\hline Moldova (Republic of) & 0.660 & 0.584 & 33.0 \\
\hline India & 0.554 & 0.392 & 33.4 \\
\hline Indonesia & 0.629 & 0.514 & 34.0 \\
\hline Jordan & 0.700 & 0.568 & 35.4 \\
\hline Vietnam & 0.617 & 0.531 & 35.6 \\
\hline Syrian Arab Republic & 0.648 & 0.515 & 35.8 \\
\hline Kyrgyzstan & 0.622 & 0.516 & 36.2 \\
\hline Mongolia & 0.675 & 0.568 & 36.5 \\
\hline Uzbekistan & 0.654 & 0.551 & 36.7 \\
\hline Lao People's Democratic Republic & 0.543 & 0.409 & 36.7 \\
\hline Maldives & 0.688 & 0.515 & 37.4 \\
\hline Cambodia & 0.543 & 0.402 & 37.9 \\
\hline Bhutan & 0.538 & 0.430 & 38.1 \\
\hline Thailand & 0.690 & 0.543 & 40.0 \\
\hline Nicaragua & 0.599 & 0.434 & 40.5 \\
\hline Morocco & 0.591 & 0.415 & 40.9 \\
\hline Gabon & 0.683 & 0.550 & 41.5 \\
\hline China & 0.699 & 0.543 & 42.5 \\
\hline Ghana & 0.558 & 0.379 & 42.8 \\
\hline Philippines & 0.654 & 0.524 & 43.0 \\
\hline Dominican Republic & 0.702 & 0.510 & 47.2 \\
\hline El Salvador & 0.680 & 0.499 & 48.3 \\
\hline Swaziland & 0.536 & 0.346 & 51.5 \\
\hline Guatemala & 0.581 & 0.389 & 55.9 \\
\hline Bolivia (Plurinational State of) & 0.675 & 0.444 & 56.3 \\
\hline Honduras & 0.632 & 0.458 & 57.0 \\
\hline Namibia & 0.608 & 0.344 & 63.9 \\
\hline
\end{tabular}

Source: Human Development Report 2013, UNDP. 


\section{Macrothink \\ Research in Applied Economics \\ ISSN 1948-5433 \\ 2014, Vol. 6, No. 3}

Table 4. HDI and Gini Coefficient of Low HDI Countries

\begin{tabular}{|c|c|c|c|}
\hline Country & $\begin{array}{l}\text { Human } \\
\text { Development } \\
\text { Index (HDI) } 2012\end{array}$ & $\begin{array}{l}\text { Inequality-adjusted } \\
\text { HDI (IHDI) } 2012\end{array}$ & $\begin{array}{l}\text { Income Gini } \\
\text { coefficient } \\
2000-2010\end{array}$ \\
\hline Ethiopia & 0.396 & 0.269 & 29.8 \\
\hline Pakistan & 0.515 & 0.356 & 30.0 \\
\hline Bangladesh & 0.515 & 0.374 & 32.1 \\
\hline Nepal & 0.463 & 0.304 & 32.8 \\
\hline Togo & 0.459 & 0.305 & 34.4 \\
\hline Niger & 0.304 & 0.200 & 34.6 \\
\hline Guinea-Bissau & 0.364 & 0.213 & 35.5 \\
\hline Tanzania (United Republic of) & 0.476 & 0.346 & 37.6 \\
\hline Yemen & 0.458 & 0.310 & 37.7 \\
\hline Liberia & 0.388 & 0.251 & 38.2 \\
\hline Benin & 0.436 & 0.280 & 38.6 \\
\hline Cameroon & 0.495 & 0.330 & 38.9 \\
\hline Malawi & 0.418 & 0.287 & 39.0 \\
\hline Senegal & 0.470 & 0.315 & 39.2 \\
\hline Guinea & 0.355 & 0.217 & 39.4 \\
\hline Chad & 0.340 & 0.203 & 39.8 \\
\hline Burkina Faso & 0.343 & 0.226 & 39.8 \\
\hline Djibouti & 0.445 & 0.285 & 40.0 \\
\hline Mauritania & 0.467 & 0.306 & 40.5 \\
\hline Côte d'Ivoire & 0.432 & 0.265 & 41.5 \\
\hline Sierra Leone & 0.359 & 0.210 & 42.5 \\
\hline Madagascar & 0.483 & 0.335 & 44.1 \\
\hline Uganda & 0.456 & 0.303 & 44.3 \\
\hline $\begin{array}{l}\text { Congo (Democratic Republic of } \\
\text { the) }\end{array}$ & 0.304 & 0.183 & 44.4 \\
\hline Mozambique & 0.327 & 0.220 & 45.7 \\
\hline Congo & 0.534 & 0.368 & 47.3 \\
\hline Kenya & 0.519 & 0.344 & 47.7 \\
\hline Nigeria & 0.471 & 0.276 & 48.8 \\
\hline Sao Tome and Principe & 0.525 & 0.358 & 50.8 \\
\hline Lesotho & 0.461 & 0.296 & 52.5 \\
\hline Rwanda & 0.434 & 0.287 & 53.1 \\
\hline Zambia & 0.448 & 0.283 & 54.6 \\
\hline Central African Republic & 0.352 & 0.209 & 56.3 \\
\hline Angola & 0.508 & 0.285 & 58.6 \\
\hline Haiti & 0.456 & 0.273 & 59.2 \\
\hline
\end{tabular}

Source: Human Development Report 2013, UNDP. 


\section{Macrothink \\ Research in Applied Economics \\ ISSN 1948-5433 \\ 2014, Vol. 6, No. 3}

\section{Income Inequality in the US}

There has been a significant increase in income inequality in the United States. Table 5 and Figure 9 show the inequality for US workers between 1967 and 2010. Inequality has increased for both men and women as the following graph shows. Also, the increase in income inequality among men has been greater than that among women during this period. This has led to an increase in the difference in inequality between the genders as Figure 10 indicates. Further research can be conducted to explore the reasons for the faster growth in income inequality among men than women and its possible consequences for the US labor market.

Table 5. Inequality for US Workers by Gender, 1967-2010

\begin{tabular}{|c|c|c|c|c|}
\hline \multirow[t]{2}{*}{ Year } & \multicolumn{4}{|c|}{ Gini Coefficient } \\
\hline & Both sexes combined & Men & Women & Difference \\
\hline 1967 & 0.340 & 0.314 & 0.298 & 0.016 \\
\hline 1968 & 0.333 & 0.308 & 0.279 & 0.029 \\
\hline 1969 & 0.326 & 0.305 & 0.264 & 0.041 \\
\hline 1970 & 0.326 & 0.305 & 0.272 & 0.033 \\
\hline 1971 & 0.328 & 0.309 & 0.268 & 0.041 \\
\hline 1972 & 0.336 & 0.316 & 0.271 & 0.045 \\
\hline 1973 & 0.330 & 0.309 & 0.261 & 0.048 \\
\hline 1974 & 0.326 & 0.309 & 0.250 & 0.059 \\
\hline 1975 & 0.327 & 0.308 & 0.260 & 0.048 \\
\hline 1976 & 0.328 & 0.311 & 0.259 & 0.052 \\
\hline 1977 & 0.332 & 0.315 & 0.260 & 0.055 \\
\hline 1978 & 0.333 & 0.316 & 0.259 & 0.057 \\
\hline 1979 & 0.335 & 0.317 & 0.264 & 0.053 \\
\hline 1980 & 0.331 & 0.315 & 0.265 & 0.050 \\
\hline 1981 & 0.334 & 0.321 & 0.266 & 0.055 \\
\hline 1982 & 0.340 & 0.330 & 0.278 & 0.052 \\
\hline 1983 & 0.340 & 0.332 & 0.280 & 0.052 \\
\hline 1984 & 0.342 & 0.332 & 0.285 & 0.047 \\
\hline 1985 & 0.348 & 0.343 & 0.289 & 0.054 \\
\hline 1986 & 0.355 & 0.349 & 0.299 & 0.050 \\
\hline 1987 & 0.353 & 0.347 & 0.300 & 0.047 \\
\hline 1988 & 0.355 & 0.350 & 0.306 & 0.044 \\
\hline 1989 & 0.362 & 0.361 & 0.310 & 0.051 \\
\hline 1990 & 0.359 & 0.361 & 0.308 & 0.053 \\
\hline 1991 & 0.355 & 0.354 & 0.311 & 0.043 \\
\hline 1992 & 0.360 & 0.363 & 0.312 & 0.051 \\
\hline 1993 & 0.389 & 0.397 & 0.336 & 0.061 \\
\hline 1994 & 0.395 & 0.403 & 0.343 & 0.060 \\
\hline 1995 & 0.388 & 0.398 & 0.332 & 0.066 \\
\hline 1996 & 0.393 & 0.401 & 0.343 & 0.058 \\
\hline 1997 & 0.394 & 0.403 & 0.341 & 0.062 \\
\hline 1998 & 0.393 & 0.401 & 0.345 & 0.056 \\
\hline 1999 & 0.399 & 0.408 & 0.344 & 0.064 \\
\hline
\end{tabular}




\section{Macrothink}

Research in Applied Economics

ISSN 1948-5433

2014, Vol. 6, No. 3

\begin{tabular}{lllll}
2000 & 0.405 & 0.418 & 0.345 & 0.073 \\
2001 & 0.409 & 0.419 & 0.362 & 0.057 \\
2002 & 0.405 & 0.418 & 0.352 & 0.066 \\
2003 & 0.401 & 0.410 & 0.359 & 0.051 \\
2004 & 0.405 & 0.418 & 0.355 & 0.063 \\
2005 & 0.409 & 0.424 & 0.357 & 0.067 \\
2006 & 0.411 & 0.419 & 0.373 & 0.046 \\
2007 & 0.394 & 0.404 & 0.356 & 0.048 \\
2008 & 0.403 & 0.416 & 0.356 & 0.060 \\
2009 & 0.404 & 0.415 & 0.365 & 0.050 \\
2010 & 0.397 & 0.408 & 0.357 & 0.051 \\
\hline
\end{tabular}

Source: US Census Bureau, Current Population Survey, Annual Social and Economic Supplements.

Note: *Author's calculation.

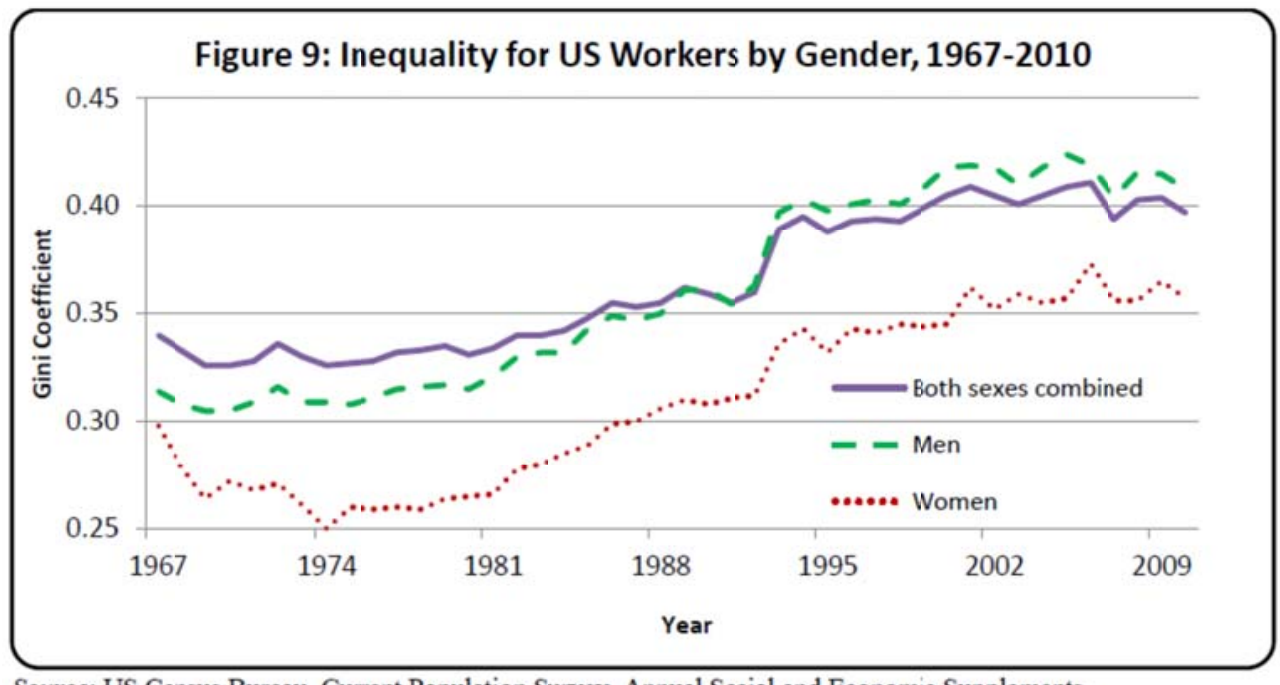

Source: US Census Bureau, Current Population Survey, Annual Social and Economic Supplements.

Figure 9. Inequality for US Workers by Gender, 1967-2010

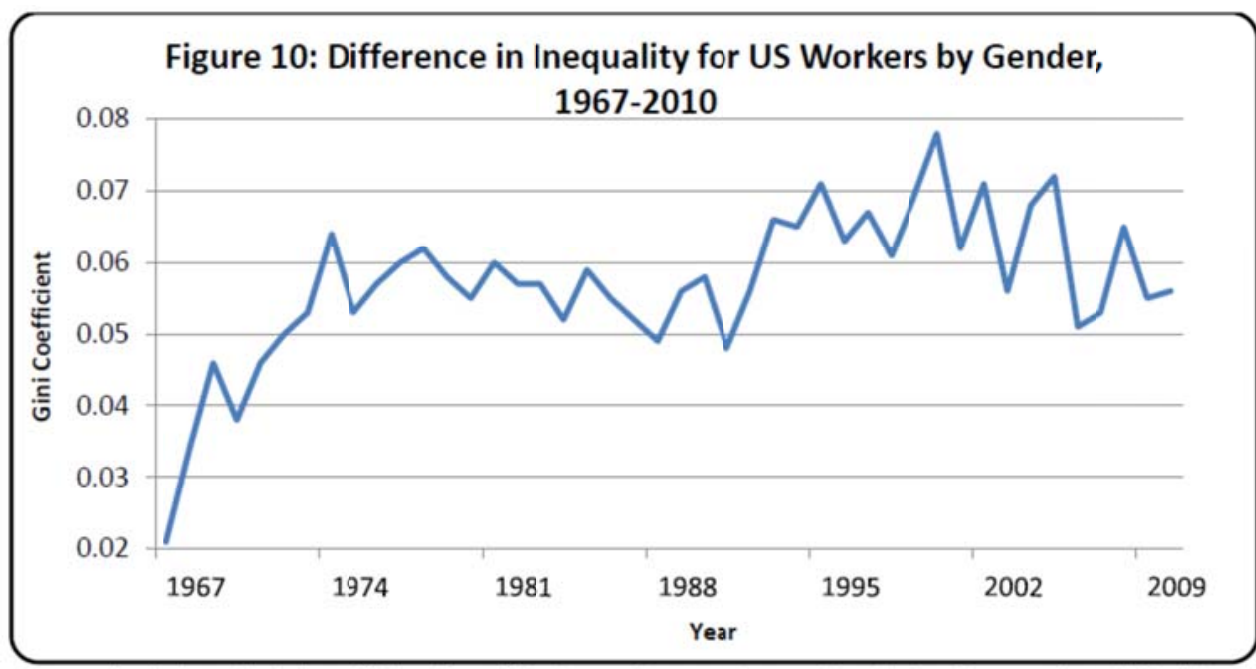

Source: Author's calculation of data from US Census Bureau, Current Population Survey, Annual Social and Economic Supplements.

Figure 10. Difference in Inequality for US Workers by Gender, 1967-2010 
10.1 Poverty and Gini Coefficient in the US

An increase in income inequality may have an influence on the poverty level. When there is wealth transfer from the poor and middle class to the rich, it is possible that the poverty level may increase. However, redistribution through taxes and benefits may reduce a possible increase in the poverty level. An analysis of the Gini coefficient and poverty level for the US can illuminate on this topic.

Table 6 and Figure 11 show the poverty level in the US from 1967 to 2010. Even though the absolute number of poor people increased during this time, the percentage of people living below the poverty level fluctuated between 11 percent and 16 percent. An analysis of Figure 9 and Figure 11 shows that while income inequality increased during this time, the percentage of people living below the poverty level stayed within this range. This may indicate that income inequality did not have a detrimental effect on the percentage of people living below the poverty level. It is also possible that welfare services and other social services helped to keep the poverty rate low. Further research can be conducted to explore the degree of influence of income inequality on poverty level.

Table 6. Poverty level in the US, 1967-2010

\begin{tabular}{lccc}
\hline Year & Total Population (in & \multicolumn{2}{c}{ People living below poverty level } \\
\cline { 2 - 4 } millions) & Number(inmillions) & Percentage \\
\hline 1967 & 195.7 & 27.8 & 14.2 \\
1968 & 197.6 & 25.4 & 12.8 \\
1969 & 199.5 & 24.1 & 12.1 \\
1970 & 202.2 & 25.4 & 12.6 \\
1971 & 204.6 & 25.6 & 12.5 \\
1972 & 206.0 & 24.5 & 11.9 \\
1973 & 207.6 & 23.0 & 11.1 \\
1974 & 209.4 & 23.4 & 11.2 \\
1975 & 210.9 & 25.9 & 12.3 \\
1976 & 212.3 & 25.0 & 11.8 \\
1977 & 213.9 & 24.7 & 11.6 \\
1978 & 215.7 & 24.5 & 11.4 \\
1979 & 222.9 & 26.1 & 11.7 \\
1980 & 225.0 & 29.3 & 13.0 \\
1981 & 227.2 & 31.8 & 14.0 \\
1982 & 229.4 & 34.4 & 15.0 \\
1983 & 231.7 & 35.3 & 15.2 \\
1984 & 233.8 & 33.7 & 14.4 \\
1985 & 236.6 & 33.1 & 14.0 \\
1986 & 238.6 & 32.4 & 13.6 \\
1987 & 241.0 & 32.2 & 13.4 \\
1988 & 243.5 & 31.7 & 13.0 \\
1989 & 246.0 & 31.5 & 12.8 \\
\hline
\end{tabular}




\begin{tabular}{llll}
\hline 1990 & 248.6 & 33.6 & 13.5 \\
1991 & 251.2 & 35.7 & 14.2 \\
1992 & 256.5 & 38.0 & 14.8 \\
1993 & 259.3 & 39.3 & 15.1 \\
1994 & 261.6 & 38.1 & 14.5 \\
1995 & 263.7 & 36.4 & 13.8 \\
1996 & 266.2 & 36.5 & 13.7 \\
1997 & 268.5 & 35.6 & 13.3 \\
1998 & 271.1 & 34.5 & 12.7 \\
1999 & 276.2 & 32.8 & 11.9 \\
2000 & 278.9 & 31.6 & 11.3 \\
2001 & 281.5 & 32.9 & 11.7 \\
2002 & 285.3 & 34.6 & 12.1 \\
2003 & 287.7 & 35.9 & 12.5 \\
2004 & 290.6 & 37.0 & 12.7 \\
2005 & 293.1 & 37.0 & 12.6 \\
2006 & 296.5 & 36.5 & 12.3 \\
2007 & 298.7 & 37.3 & 12.5 \\
2008 & 301.0 & 39.8 & 13.2 \\
2009 & 303.8 & 43.6 & 14.3 \\
2010 & 306.1 & 46.3 & 15.1 \\
\hline
\end{tabular}

Source: US Census Bureau, Current Population Survey, Annual Social and Economic Supplements.

Figure 11: Percent of people living below poverty level in the US, $1967-2010$

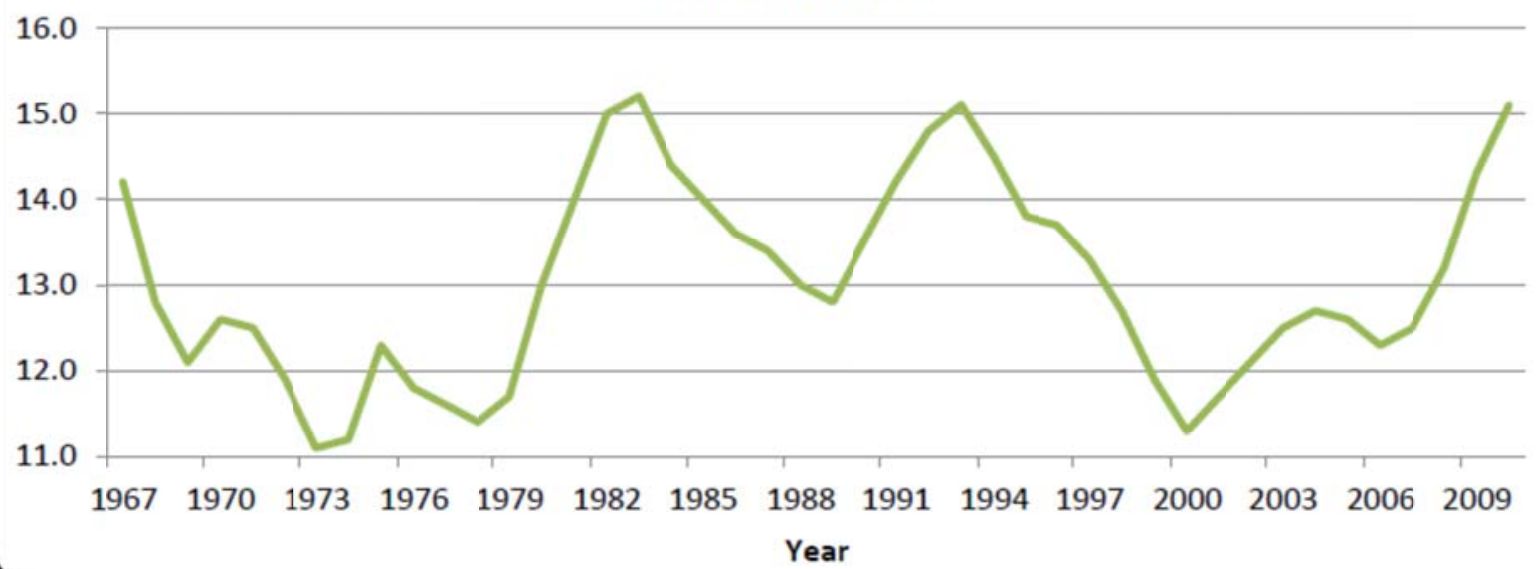

Source: US Census Bureau, Current Population Survey, Annual Social and Economic Supplements.

Figure 11. Percent of people living below poverty level in the US, 1967-2010 


\section{Possible Solutions}

If income inequality is considered a problem, there can be various policies to reign in the problem. These problems can be classified into public solutions and private solutions. Public solutions will be planned and implemented by national and international organizations. It can range from increasing the income tax rate, more transparency and regulation of tax havens and transfer pricing practices and implementing programs to raise the minimum wage and increase opportunity for the marginalized. Also, the government can implement measures to control possible rent seeking practices. Finally, national governments can cooperate so that globalization does not lead to exploitation of labor. Private solutions can be donations and charities by individuals to redistribute wealth and improve the condition of the poor. Activities like The Giving Pledge may help to reduce income inequality. However, any redistributive policy should be careful in not demoralizing talented individuals to pursue exceptional achievements.

\section{Conclusion}

Income inequality has increased all over the world, in both developed and developing countries. It is true that access to technology has allowed talented people in different occupations from hedge-fund managers to athletes to earn astronomical sums of money. However, there may be other possible reasons like differences in opportunity and globalization that this paper has explored. Due importance has to be paid to the other reasons to understand global income inequality. Any policy to curb income inequality must first identify the underlying reasons for the global income inequality.

\section{Acknowledgement}

I am grateful to Raffat Zerin for editing, helpful comments and suggestions.

\section{References}

Acemoglu, Daron, \& David Autor. (2012). "What Does Human Capital Do? A Review of Goldin and Katz"s The Race between Education and Technology." MIT working paper. http://dx.doi.org/10.3386/w17820

Acharya, Nupur. (2013). The Friday Briefing: Battle of the Economists. The Wall Street Journal. Retrieved July 26 from http://blogs.wsj.com/indiarealtime/2013/07/26/the-friday-briefing-battle-of-the-economists

Alvaredo, Facundo, Anthony B. Atkinson,Thomas Piketty, \& Emmanuel Saez. (2013). The Top 1 percent in International and Historical Perspective. Journal of Economic Perspectives, 27(3), 3-20. http://dx.doi.org/10.1257/jep.27.3.3

Bivens, Josh, \& Lawrence Mishel. (2013). The Pay of Corporate Executives and Financial 
Professionals as Evidence of Rents in Top 1 Percent Incomes. Journal of Economic Perspectives, 27(3), 57-78. http://dx.doi.org/10.1257/jep.27.3.57

Bonica, Adam, Nolan McCarty, Keith T. Poole, \& Howard Rosenthal. (2013). Why Hasn't Democracy Slowed Rising Inequality? Journal of Economic Perspectives, 27(3), 103-124. http://dx.doi.org/10.1257/jep.27.3.103

Chakrabortty, Aditya. (2013). The woman who nearly died making your iPad. The Guardian, $\begin{array}{lll}\text { Retrieved } \quad \text { August } & 5 & \text { from }\end{array}$ http://www.theguardian.com/commentisfree/2013/aug/05/woman-nearly-died-making-ipad

Chetty, Raj, \& John N. Friedman. (2011). Does Local Tax Financing of Public Schools Perpetuate Inequality? National Tax Association Proceedings. Retrieved from http://202.154.59.182/mfile/files/Umum/JURNAL\%20HARVARD/Does\%20Local\%20Ta X\%20Financing\%20of\%20Public\%20Schools\%20Perpetuate\%20Inequality.pdf

Chetty, Raj, John N. Friedman, \& Jonah E. Rockoff. (2011). The Long-Term Impacts of Teachers: Teacher Value-Added and Student Outcomes in Adulthood. NBER Working Paper No. 17699. Retrieved from http://www.nber.org/papers/w19424

Chetty, Raj, John N. Friedman, Nathaniel Hilger, Emmanuel Saez, Diane Whitmore Schanzenbach, \& Danny Yagan. (2011). How Does Your Kindergarten Classroom Affect Your Earnings? Evidence from Project Star. Quarterly Journal of Economics, 126(4), 1593-1660. http://dx.doi.org/10.1093/qje/qjr041

Corak, Miles. (2013). Income Inequality, Equality of Opportunity, and Intergenerational Mobility. Journal of Economic Perspectives, 27(3), 79-102. http://dx.doi.org/10.1257/jep.27.3.79

Duhigg, Charles, \& David Barboza. (2012). Human Costs Are Built Into an iPad. The New York Times, Retrieved January $25 \quad$ from http://www.nytimes.com/2012/01/26/business/ieconomy-apples-ipad-and-the-human-costsfor-workers-in-china.html

Edsall, Thomas B. (2012). Separate and Unequal. The New York Times, Retrieved August 3 from

http://www.nytimes.com/2012/08/05/books/review/the-price-of-inequality-by-joseph-e-stig litz.html?pagewanted=all

Forbes. (2013). The World"s Billionaires. Retrieved March 2013 from http://www.forbes.com/billionaires/

Goldin, Claudia, \& Lawrence F. Katz. (2008). The Race between Education and Technology. Cambridge, MA: Harvard University Press. Retrieved from http://www.hup.harvard.edu/catalog.php?isbn=9780674035300

Kaplan, Steven N., \& Joshua Rauh. (2013). It's the Market: The Broad-Based Rise in the Return to Top Talent. Journal of Economic Perspectives, 27(3), 35-56. http://dx.doi.org/10.1257/jep.27.3.35 
Kuznets, Simon. (1955). Economic Growth and Income Inequality. American Economic Review, 45(1), 1-28.

Mankiw, Gregory N. (2013). Defending the One Percent. Journal of Economic Perspectives, 27(3), 21-34. http://dx.doi.org/10.1257/jep.27.3.21

O’Brian, Bridget. (2012). The Price of Inequality. The Record, Columbia University, 37(11). Retrieved from http://news.columbia.edu/files_columbianews/imce_shared/vol3711.pdf

Rajan, Raghuram. (2012). Is Inequality Inhibiting Growth? Project Syndicate, Retrieved July

https://www.project-syndicate.org/commentary/is-inequality-inhibiting-growth-

Roberts, Yvonne. (201)2. The Price of Inequality by Joseph Stiglitz - review. The Guardian. Retrieved July 13 from http://www.theguardian.com/books/2012/jul/13/price-inequality-joseph-stiglitz-review

Sacerdote, Bruce. (2007). How Large are the Effects from Changes in Family Environment? A Study of Korean American Adoptees. Quarterly Journal of Economics, 122(1), 119-157. http://dx.doi.org/10.1162/qjec.122.1.119

Safdar, Khadeeja. (2013). Is High School Popularity or Family More Important to Future Earnings? The Wall Street Journal. Retrieved July 24 from http://blogs.wsj.com/economics/2013/07/24/is-high-school-popularity-or-family-more-i mportant-to-future-earnings/

Sala-i-Martin, Xavier. (2002). "The Disturbing Rise of Global Income Inequality." NBER Working Paper No. 8904. Retrieved from http://www.nber.org/papers/w8904.pdf

Sikka, Prem \& Hugh Willmott. (2010). The Dark Side of Transfer Pricing: Its role in tax avoidance and wealth retentiveness. Critical Perspectives on Accounting, 21(4), 342-356. http://dx.doi.org/10.1016/j.cpa.2010.02.004

Stiglitz, Joseph E. (2011). "Of the 1\%, by the 1\%, for the 1\%." Vanity Fair, Retrieved May 1. from http://www.vanityfair.com/society/features/2011/05/top-one-percent-201105

Stiglitz, Joseph E. (2012). "The 1 Percent’s Problem." Vanity Fair, Retrieved May 31 from http://www.vanityfair.com/politics/2012/05/joseph-stiglitz-the-price-on-inequality

Stiglitz, Joseph E. (2012). "The Price of Inequality." Project Syndicate. Retrieved June 5 from https://www.project-syndicate.org/commentary/the-price-of-inequality

United Nations Development Program. (2013). Human Development Report. Retrieved from http://hdr.undp.org/en/2013-report

Weir, Bill. (2012). "A Trip to The iFactory: 'Nightline' Gets an Unprecedented Glimpse Inside Apple's Chinese Core." ABC News. Retrieved February 20, 2012 From http://abcnews.go.com/International/trip-ifactory-nightline-unprecedented-glimpse-inside-ap ples-chinese/story?id=15748745 
Weir, Bill. (2012). "iFactory: Inside Apple." ABC Nightline, TV program, Retrieved February 21, 2012 from http://abcnews.go.com/International/trip-ifactory-nightline-unprecedented-glimpse-insi de-apples-chinese/story?id=15748745

\section{Copyright Disclaimer}

Copyright reserved by the author(s).

This article is an open-access article distributed under the terms and conditions of the Creative Commons Attribution license (http://creativecommons.org/licenses/by/3.0/). 